\title{
Blood Volume Fraction
}

National Cancer Institute

\section{Source}

National Cancer Institute. Blood Volume Fraction. NCI Thesaurus. Code C94867.

The portion of tissue occupied by blood. It is also sometimes expressed for a region as the volume of blood per unit mass of tissue. 